\title{
PENGARUH TERAPI BERMAIN HOSPITAL STORY TERHADAP KECEMASAN PADA ANAK USIA PRASEKOLAH DI RUANG RAWAT INAP RSUD PATUT PATUH PATJU KABUPATEN LOMBOK BARAT TAHUN 2018
}

\author{
Indah Putri Noviyanti ${ }^{1}$, Indah Wasliah ${ }^{2}$, Ernawati $^{3}$ \\ ${ }^{1)}$ Mahasiswa Prodi S.1 Keperawatan Stikes Yarsi Mataram \\ ${ }^{2)}$ Dosen Prodi Ners Stikes Yarsi Mataram \\ ${ }^{3)}$ Dosen Prodi S.1 Keperawatan Stikes Yarsi Mataram \\ indahwasliah@yahoo.com
}

\begin{abstract}
ABSTRAK
Kecemasan merupakan kondisi emosional yang tidak menyenangkan dan tidak diketahui jelas sebabnya seperti dampak dari hospitalisasi yakni anak akan menolak tindakan perawatan dan pengobatan, untuk mengurangi dampak tersebut diperlukan suatu media yang dapat mengungkapkan rasa cemasnya, salah satunya adalah terapi bermain. Penelitian ini bertujuan untuk Mengetahui pengaruh terapi bermain hospital story terhadap kecemasan anak usia prasekolah.

Jenis penelitian ini adalah penelitian quasi eksperimen dengan one group pretest and post tess design yaitu dilakukannya pretest terlebih dahulu kemudian setelah diberi intervensi dilakukan post test. Polulasinya adalah semua anak usia prasekolah yang dirawat di IRNA Anak RSUD Patut Patuh Patju Kabupaten Lombok Barat dengan estimasi 19 orang, sampel penelitian ini diambil dengan menggunakan teknik non probability sampling dengan purposive sampling sehingga didapatkan sampel sebanyak 19 orang.

Hasil penelitian menggunakan Analisis statistik uji parametrik didapatkan nilai $\mathrm{p}=$ $0,000(<\alpha=0,05)$ menunjukkan ada pengaruh terapi bermain hospital story terhadap kecemasan anak usia prasekolah, maka hipotesa alternatif terbukti.

Diharapkan kepada petugas kesehatan agar mengoptimalkan pemberian terapi bermain kepada anak yang dirawat agar dapat mengoptimalkan perawatan dan pengobatan terhadap anak.
\end{abstract}

Kata kunci : Terapi Bermain; Kecemasan; Anak Prasekolah; Hospitalisasi.

\section{PENDAHULUAN}

Hospitalisasi merupakan kebutuhan klien untuk dirawat karena adanya perubahan atau gangguan fisik, psikis, sosial dan adaptasi terhadap lingkungan. Sakit dan dirawat dirumah sakit merupakan krisis utama yang tampak pada anak. Anak yang dirawat di rumah sakit akan mudah mengalami krisis dan masalah seperti anak mengalami stress, dan anak mempunyai sejumlah keterbatasan dalam mekanisme koping (Wong, 2009).

Respon anak terhadap hospitalisasi dipengaruhi oleh tahapan usia perkembangan, pengalaman sebelumnya terhadap sakit, mekanisme pertahanan diri yang dimiliki, dan sistem dukungan yang tersedia. Permasalahan yang muncul terkait respon anak terhadap hospitalisasi adalah banyak anak 
menolak saat menjalani perawatan di rumah sakit karena harus menyesuaikan diri dengan lingkungan rumah sakit yang asing, apalagi menjalani rawat inap dalam jangka waktu yang lama. Peralatan medis yang terlihat bersih dan prosedur medis dianggap anak menyakitkan dan membahayakan karena dapat menimbulkan terjadinya kecemasan anak.

Kecemasan merupakan kondisi emosional yang tidak menyenangkan yang ditandai oleh perasaan-perasaan subjektif atau perasaan yang tidak diketahui jelas sebabnya atau sumbernya seperti ketegangan, ketakutan, dan kekhawatiran. Respon anak terhadap kecemasan bervariasi, dipengaruhi oleh berbagai faktor antara lain : akibat perubahan status kesehatan maupun lingkungan dalam kebiasaan sehari-hari, keterbatasan dalam mekanisme koping untuk mengatasi masalah maupun kejadian-kejadian yang bersifat menekan (Whaley \& Wong, 1998 dalam Nursalam, 2005).

Selain itu faktor yang mendukung yaitu usia perkembangan anak, jenis kelamin, lama perawatan, dan pengalaman sebelumnya terhadap sakit. Anak usia prasekolah biasanya mengalami sepation anxiety atau kecemasan perpisahan karena anak harus berpisah dengan lingkungan yang dirasakannya nyaman, penuh kasih sayang, dan menyenangkan seperti lingkungan rumah, permainan, dan teman sepermainannya. Kecemasan terbesar pada anak usia prasekolah selama menjalani hospitalisasi adalah kecemasan terjadinya perlukaan pada bagian tubuhnya. Semua prosedur atau tindakan keperawatan baik yang menimbulkan nyeri maupun tidak dapat menyebabkan kecemasan anak prasekolah.
Usia prasekolah merupakan masa kritis dalam tahap perkembangan. Pada tahap ini anak telah mampu menggunakan simbol-simbol yaitu menggunakan kata-kata, mengingat masa lalu, sekarang dan yang akan terjadi, termasuk kemampuan anak dalam belajar mengendalikan, memanipulasi lingkungan seperti kemampuan adaptasi terhadap hospitalisasi yang dipengaruhi oleh lamanya dirawat di rumah sakit, dukungan dan fasilitas dari keluarga, pengalaman hospitalisasi sebelumnya, rekreasi dan aktivitas bermain anak (Rudolp, 2002).

Reaksi anak usia prasekolah yang menolak makan, menangis diam-diam karena kepergian mereka, sering bertanya tentang keadaan dirinya, mengalami sulit tidur, tidak kooperatif terhadap petugas kesehatan saat dilakukan tindakan keperawatan. Dampak dari kecemasan pada anak yang mengalami perawatan, apabila tidak segera ditangani akan membuat anak melakukan penolakan terjadap tindakan keperawatan dan pengobatan sehingga akan berpengaruh terhadap lamanya hari rawat anak dan dapat memperberat kondisi penyakit yang diderita anak. Untuk mengurangi dampak akibat hospitalisasi yang dialami anak selama menjalani pearawatan, diperlukan suatu media yang dapat mengungkapkan rasa cemasnya, salah satunya adalah terapi bermain.

Terapi bermain merupakan suatu aktivitas dimana anak dapat melakukan atau mempraktikkan keterampilan, memberikan ekspresi terhadap pemikiran, menjadi kreatif, mempersiapkan diri untuk berperan dan berperilaku dewasa (Adriana, 2011). Anak memerlukan berbagai variasi permainan untuk kesehatan fisik, mental dan perkembangan emosinya. Anak tidak sekedar melompat, melempar atau 
berlari tetapi mereka bermain menggunakan seluruh emosi, perasaan dan pikirannya (Supartini, 2004).

Hospital story adalah suatu aktivitas bermain dengan menceritakan semua hal yang berkaitan dengan rumah sakit, khususnya tentang rutinitas kegiatan, mengenal tim kesehatan, dan prosedur pengobatan, melalui media buku cerita bergambar. Hospital story termasuk aktivitas bermain admission activities yaitu aktivitas bermain yang dilakukan segera setelah anak datang ke rumah sakit. Ada beberapa fungsi bermain di rumah sakit antara lain : mengenalkan anak pada lingkungan dan keadaan asing, mengajarkan untuk bisa membuat keputusan dan kontrol, untuk mengurangi stres dan cemas, untuk mengurangi nyeri, mengenalkan tentang tujuan dan penggunaan alat medis (Wong, 2004).

Prevalensi anak yang menjalani perawatan di rūmah sakit menurut UNICEF tahun 2012 sekitar 84\% dan berdasarkan Riset Kesehatan Dasar (RISKESDAS) tahun 2013 didapatkan data rata-rata anak yang menjalani rawat inap di rumah sakit di seluruh indonesia adalah $2.8 \%$ dari total jumlah anak 82.666 orang. Di Indonesia angka kesakitan anak yang dirawat di rumah sakit cukup tinggi, sekitar 35 per 1000 anak menderita sakit yang ditunjukkan dengan selalu penuhnya ruangan anak baik rumah sakit pemerintah maupun swasta. Hal ini yang menimbulkan stres hospitalisasi (Sumaryoko, 2008).

Data dari ruang anak RSUD Patut Patuh Patju Kabupaten Lombok Barat bahwa jumlah anak usia prasekolah yang dirawat di ruang perawatan anak selama tiga tahun terakhir mengalami peningkatan dari tahun 2015 sampai tahun 2017 yaitu pada tahun 2015 pasien anak yang dirawat berjumlah 119 orang, tahun 2016 berjumlah 183 orang, dan pada tahun 2017 berjumlah 190 orang.
Dengan total keseluruhan 492 anak, ratarata jumlah anak yang dirawat 19-20 orang anak tiap bulannya. Berdasarkan hasil study pendahuluan yang peneliti lakukan terhadap 10 orang anak, didapatkan 3 anak menangis saat didekati perawat, 2 anak takut, 4 anak cemas dan 1 anak lainnya tidak kooperatif dengan petugas kesehatan saat akan dilakukan tindakan keperawatan.

Berdasarkan latar belakang di atas maka penelitian ini bertujuan untuk mengetahui Pengaruh terapi bermain hospital story terhadap tingkat kecemasan anak usia prasekolah di ruang anak RSUD Patut Patuh Patju Gerung Kabupaten Lombok Barat

\section{BAHAN DAN METODE}

Penelitian ini adalah penelitian quasi eksperimen dengan one group pretest and post test designt. Populasi dalam penelitian ini adalah semua anak usia prasekolah yang dirawat di IRNA Anak RSUD Patut Patuh Patju Kabupaten Lombok Barat dengan estimasi 19 orang yang didapat dari ratarata jumlah anak usia prasekolah yang dirawat selama 3 bulan terakhir tahun 2017.

Sampel penelitiannya adalah anak usia prasekolah yang dirawat di ruang IRNA Anak RSUD Patut Patuh Patju Kabupaten Lombok Barat sebanyak 16 orang. Sampel pada penelitian ini diambil menggunakan teknik Purposive Sampling, dengan terlebih dahulu mengidentifikasi responden berdasarkan kriteria inklusi yang telah ditetapkan dan melakukan inform consent. Analisa data hasil penelitian ini dilakukan dengan 2 cara yaitu Analisis Univariat dan Bivariat. uji statistic menggunakan parametrik dengan nilai $p$ value $=$ $0,000(<\alpha=0,05), \quad$ Pengolahan serta 
analisis data dilakukan kemudian dengan menggunakan komputer dengan program SPSS.16.

\section{HASIL DAN BAHASAN}

\section{HASIL}

\section{Data Umum Responden}

1.1 Karakteristik responden berdasarkan umur

Tabel 1.1 menunjukkan distribusi umur responden yang paling banyak yaitu berada pada kelompok umur 4 tahun yaitu sebanyak 8 orang $(42,1 \%)$, dan yang terendah pada umur 6 tahun yaitu sebanyak 1 orang $(5,3 \%)$.

\begin{tabular}{llll}
\hline No & Umur & $\mathbf{n}$ & \% \\
\hline 1 & 3 & 3 & 15.8 \\
2 & 4 & 8 & 42.1 \\
3 & 5 & 7 & 36.8 \\
4 & 6 & 1 & 5.3 \\
\hline \multicolumn{4}{l}{ Total } \\
\multicolumn{4}{l}{ Sumber :Data } \\
Primer 2018
\end{tabular}

1.2 Karakteristik responden berdasarkan Jenis Kelamin Tabel 1.2 menunjukkan distribusi jenis kelamin responden yang paling banyak yaitu perempuan sebanyak12 orang (63,2\%), sedangkan laki-laki hanya 7 orang $(36,8 \%)$.

\begin{tabular}{llll}
\hline No & Jenis Kelamin & n & \% \\
\hline 1 & Laki-Laki & 7 & 36.8 \\
2 & Perempuan & 12 & 63.2 \\
\hline Total & $\mathbf{1 9}$ & $\mathbf{1 0 0 . 0}$ \\
\hline
\end{tabular}

Sumber :Data Primer 2018

1.3 Karakteristik Responden Berdasarkan Tingkat Pendidikan Orang Tua

Tabel 1.3 Menunjukkan distribusi pendidikan orang tua responden yang paling banyak yaitu berpendidikan SMA dengan jumlah responden 10 orang $(52,6 \%)$, dan tidak ada responden yang tidak pernah sekolah..

\begin{tabular}{llll}
\hline No & Tingkat pendidikan & $\mathbf{N}$ & $\mathbf{\%}$ \\
\hline 1 & Tidak Sekolah & 0 & 0 \\
2 & Sekolah Dasar & 3 & 15.8 \\
3 & SLTP & 2 & 10.5 \\
4 & SLTA & 10 & 52.6 \\
5 & DIII/PerguruanTinggi & 4 & 21.1 \\
\hline \multicolumn{2}{l}{ Total } & $\mathbf{1 9}$ & $\mathbf{1 0 0 . 0}$ \\
\hline \multicolumn{4}{l}{ Sumber :Data Primer }
\end{tabular}

1.4 Karakteristik Responden berdasarkan Pekerjaan Orang Tua.

Tabel 1.4 Menunjukkan bahwa sebagian besar responden tidak bekerja atau sebagai ibu rumah tangga yaitu sebanyak 10 orang $(52,6 \%)$ dan jenis pekerjaan yang paling sedikit adalah PNS sebanyak 2 orang $(10,5 \%)$.

\begin{tabular}{llll}
\hline No & Pekerjaan & N & \% \\
\hline 1 & PNS/TNI/POLRI & 2 & 10.5 \\
2 & Wiraswasta & 7 & 36.8 \\
3 & Tidak Ada Pekerjaan Tetap & 10 & 52.6 \\
\hline \multicolumn{2}{l}{ Total } & $\mathbf{1 9}$ & $\mathbf{1 0 0 . 0}$ \\
\hline \multicolumn{2}{l}{ Sumber :Data Primer } & 2018
\end{tabular}

\section{Data Khusus}

2.1 Gambaran Tingkat Kecemasan Anak Usia Prasekolah sebelum dilakukannya Terapi bermain Hospital Story

Tabel 2.1. Menunjukkan bahwa tingkat kecemasan responden sebelum mendapatkan terapi bermain sebagian besar memiliki tingkat kecemasan berat, yaitu sebanyak 16 orang $(84,2 \%)$

\begin{tabular}{lllc}
\hline No & Tingkat Kecemasan & n & \% \\
\hline 1 & Tidak Ada Kecemasan & 0 & 0.0 \\
2 & Kecemasan Ringan & 0 & 0.0 \\
3 & Kecemasan Sedang & 3 & 15.8 \\
4 & Kecemasan Berat & 16 & 84.2 \\
\hline Total & $\mathbf{1 9}$ & $\mathbf{1 0 0 . 0}$
\end{tabular}

Sumber :Data Primer 2018

2.2 Gambaran Tingkat Kecemasan anak usia prasekolah setelah dilakukannya terapi bermain hospital story 
Tabel 2.2 Menunjukkan bahwa tingkat kecemasan responden sesudah mendapatkan terapi bermain sebagian besar mengalami penurunan tingkat kecemasan. Tingkat kecemasan responden yang paling banyak adalah tingkat kecemasan sedang dengan jumlah 10 orang $(52,6 \%)$.

\begin{tabular}{llcl}
\hline No & Pengetahuan Keluarga & n & \% \\
\hline 1 & Tidak Ada Kecemasan & 2 & 10.5 \\
2 & Kecemasan Ringan & 7 & 36.8 \\
3 & Kecemasan Sedang & 10 & 52.6 \\
4 & Kecemasan Berat & 0 & 0 \\
\hline \multicolumn{2}{l}{ Total } & $\mathbf{1 9}$ & $\mathbf{1 0 0 . 0}$
\end{tabular}

Sumber :Data Primer 2018

2.3 PengaruhTerapi Bermain Hospital Story Terhadap Kecemasan Anak Usia Prasekolah di Ruang Anak RSUD Patuh Patut Patju Gerung Kabupaten Lombok Barat.

Tabel 2.3 Berdasarkan hasil uji statistic menggunakan parametrik di dapatkan nilai $\mathrm{p}=0,000(<\alpha$ $=0,05)$, maka hipotesa diterima yaitu ada pengaruh terapi bermain hospital story terhadap kecemasan anak usia prasekolah di Ruang Anak RSUD Patut Patuh Patju Gerung Kabupaten Lombok Barat Tahun 2018.

\begin{tabular}{clccc}
\hline No & TerapiBermain & n & Rerata \pm s.b. & $\boldsymbol{p}$ \\
\hline 1 & $\begin{array}{l}\text { Kecemasan Sebelum } \\
\text { (hospital story) }\end{array}$ & 19 & $3,84 \pm 0,38$ & $<0.001$ \\
2 & $\begin{array}{l}\text { Kecemasan Sesudah } \\
\text { (hospital story) }\end{array}$ & 19 & $2,42 \pm 0,69$ & \\
\hline
\end{tabular}

Sumber :Paired T-test

\section{BAHASAN}

\section{Kecemasan Anak Sebelum Diberikan Terapi Bermain}

Berdasarkan hasil penelitian yang telah dilakukan terhadap 19 responden dengan menggunakan instrumen penelitian berupa kuesioner sebelum diberikan terapi bermaindiperoleh data sebanyak 16 responden $(84,2 \%)$ memiliki tingkat kecemasan yang berat, dan 3 responden $(15,8 \%)$ memiliki tingkat kecemasan yang sedang. Tingginya persentase jumlah responden yang memiliki tingkat kecemasan yang beratdapat disebabkan oleh berbagai faktor diantaranya adalah dampak dari hospitalisasi yang di alami oleh anak karena menghadapi stressor yang ada di lingkungan rumah sakit.

Pada umumnya reaksi anak terhadap sakit adalah kecemasan karena perpisahan dan kehilangan. Pada masa anak reaksi anak terhadap hospitalisasi adalah menolak makan, sering bertanya, menangis perlahan, tidak kooperatif terhadap petugas kesehatan. Sehingga perawatan di rumah sakit menjadi kehilangan kontrol dan pembatasan aktivitas. Sering kali hospitalisasi di persepsikan oleh anak sebagai hukuman, sehingga ada perasaan malu, takut yang menimbulkan reaksi agresif, marah, berontak, tidak mau bekerjasama dengan perawat (Jovan, 2007).

Hal ini sejalan dengan penelitian Tjahjono yang mengemukakan bahwa kecemasan mengakibatkan anak tidak mampu mengekspresikan perasaan dan pikiran cemas, takut, sedih, tegang, nyeri dan anak tidak kooperatif terhadap tindakan keperawatan yang diberikan.

\section{Kecemasan Anak Sesudah Diberikan Terapi Bermain}

Hasil penelitian ini memperlihatkan bahwa adanya pengaruh pemberian terapi bermain terhadap penurunan tingkat kecemasan anak. Terlihat pada tabel 5.6 bahwa tingkat kecemasan anak setelah diberikan terapi bermain yang pada awalnya ada beberapa anak yang 
memiliki tingkat kecemasan tinggi menjadi tidak ada dan yang tampak adalah anak yang tidak memiliki tingkat kecemasan sama sekali walaupun hanya 2 orang dari total 19 orang anak.

Anak yang dirawat di rumah sakit mengalami respon kecemasan, tetapi setelah di beri terapi bermain respon kecemasan tersebut menurun dari cemas berat menurun menjadi cemas sedang dan dari cemas sedang menurun menjadi cemas ringan kemudian pada cemas ringan yang semula terdapat tiga atau dua gejala menurun menjadi dua atau satu gejala. Hal ini menunjukkan penurunan kecemasan yang sangat signifikan. Terbukti bahwa permainan mampu menurunkan kecemasan, sebagaimana penelitian Yusnita Pratiwi Tahun 2012 yang menunjukkan bahwa permainan mampu menurunkan kecemasan anak.

Terapi bermain merupakan gambaran penting dan bagian dari peran perawat yang profesional dalam upaya promosi kesehatan dan pencegahan penyakit (preventif) yang telah dilakukan sejak tahun 1959 pada zaman Florence Nightingale. Terapi bermain merupakan bentuk kegiatan dan pelayanan keperawatan yang dilakukan di Rumah Sakit, Puskesmas ataupun di luar Puskesmas seperti posyandu atau lingkungan masyarakat (Nursalam, 2008). Hal ini sejalan dengan penelitian yang dilakukan oleh Lina Indrawati tahun 2013 yang dimana di dapatkan adanya pengaruh pemberian terapi aktivitas bermain terhadap tingkat kecemasan anak usia toddler akibat hospitalisasi.

\section{Pengaruh Terapi Bermain Hospital Story Terhadap Kecemasan Anak Usia Prasekolah}

Berdasarkan hasil uji statistic menggunakan uji T-test diperoleh nilai $p=0,000<\alpha=0,05$, maka hipotesa diterima yaitu ada pengaruh terapi bermain hospital story terhadap kecemasan anak usia prasekolah di Ruang Anak RSUD Patut Patuh Patju Gerung Kabupaten Lombok Barat Tahun 2018.

Hal ini sejalan dengan penelitian dari Lina Indawati tahun 2013 yang menyatakan Ada pengaruh antara pemberian terapi aktivitas bermain terhadap tingkat kecemasan anak usia toddler akibat hospitalisasi. Hospitalisasi dapat mengakibatkan tingkat kecemasan anak meningkat. Terapi aktivitas bermain merupakan terapi yang sifatnya memberikan permainan yang bertujuan untuk mengurangi tingkat kecemasan yang akan berujung pada stress akibat dari hospitalisasi.

Hal ini sejalan menurut Nursalam tahun 2005 bermain adalah untuk kesehatan mental, emosional dan sosial. Oleh karena itu, adanya ruang bermain khusus bagi anak adalah sangat penting untuk memberikan rasa aman dan menyenangkan. Berdasarkan hasil penelitian ini memungkinkan adanya kontribusi yang baik dalam penurunan tingkat kecemasan anak salah satunya dengan keterlibatan keluarga serta peran perawat dalam merawat merawat anak yang sedang dirawat di rumah sakit dengan memberikan cerita-cerita atau membicarakan hal yang disenanginya. Hal ini sejalan dengan penelitian Yusnita Pratiwi tahun 2012 yang mengemukakan bahwa ada perbedaan sebelum diberi terapi bermain dan setelah diberi terapi bermain. Dapat dilihat bahwa sebelum diberi terapi bermain ada anak yang mengalami cemas sedang dan berat tetapi setelah diberi terapi 
bermain anak yang cemas sedang menurun menjadi cemas ringan dan cemas berat menjadi cemas sedang hal ini membuktikan bahwa ada pengaruh terapi bermain terhadap respon kecemasan anak usia pra sekolah di ruang perawatan anak RSUD Patut Patuh Patju Lombok Barat.

\section{SIMPULAN DAN SARAN}

\section{Simpulan}

1. Tingkat kecemasan anak usia prasekolah sebelum diberikan terapi bermain hospital story didapatkan hasil kecemasan ringan tidak ada, kecemasan sedang 3 orang dan kecemasan berat 16 orang.

2. Tingkat kecemasan anak usia prasekolah setelah dilakukan terapi bermain hospital story didapatkan hasil tidak ada kecemasan 2 orang, kecemasan ringan 7 orang, kecemasan sedang 10 orang dan kecemasan berat tidak ada.

3. Dari hasil uji statistic Paired T-test diperoleh nilai $\mathrm{p}=0,000<\alpha=0,05$, maka hipotesa diterima yaitu ada pengaruh terapi bermain hospital story terhadap kecemasan anak usia prasekolah di Ruang Anak RSUD Patut Patuh Patju Gerung Kabupaten Lombok Barat Tahun 2018.

\section{Saran}

\section{Bagi Pelayan Kesehatan}

Dengan telah dilaksanakan penelitian ini maka perawat dapat memahami bahwa pentingnya dilakukan terapi bermain dan dapat diterapkan dalam pekerjaan sehingga dapat meningkatkan mutu pelayanan asuhan keperawatan pada anak usia prasekolah.

2. Bagi Ilmu Keperawatan

Agar dari hasil penelitian ini dapat menjadi masukkan di dalam pembelajaran mata kuliah keperawatan anak khususnya terkait dengan cara dan strategi perawatan khususnya di ruang anak sehingga dapat meminimalkan kecemasan hospitalisasi pada anak usia prasekolah.

3. Bagi Peneliti Selanjutnya

Dengan telah dilaksanakan penelitian ini bisa dilanjutkan untuk melihat sejauh mana pengaruh terapi bermain terhadap angka penurunan tingkat kecemasan, serta menambah wawasan tentang pengetahuan keluarga dalam menyikapi kecemasan anak.

\section{DAFTAR PUSTAKA}

Arikunto, S, (2013). Prosedur Penelitian: Suatu Pendekatan Praktik. Jakarta: Rineka Cipta.

Dahlan, Sopiyudin, (2011). Statistik Untuk Kedokteran dan Kesehatan. Jakarta: Salemba Medika.

Elfira, Eqlima, (2011). Pengaruh Terapi Bermain dengan Tehnik Bercerita Terhadap Kecemasan Akibat Hospitalisasi Pada Anak. Medan; Skripsi Fakultas Keperawatan Universitas Sumatera Utara.

Hidayat, Alimul Aziz, (2005). Pengantar Ilmu Keperawatan Anak I. Jakarta: Salemba Medika.

Hidayat, Azwar, (2010). Metode Penelitian Tehnik Analisis Data Cetakan Ke Empat.Jakarta: Salemba Medika.

Hurlock, Elizabeth, (2005). Perkembangan Anak (Terjemahan Meitasari Tjandrasa). Surabaya: Erlangga. 
Musfiroh, Tadkiroatun, (2007). Cerdas Melalui Bermain. Jakarta: Grasindo.

Notoatmodjo, Soekidjo, (2012). Prinsipprinsip Dasar Ilmu Kesehatan Masyarakat. Jakarta: Rineka Cipta. -(2010).

Metodologi Penelitian Kesehatan. Jakarta: Rineka Cipta.

Nursalam. 2011. Konsep dan Penerapan Metodelogi Penelitian Ilmu Keperawatan. Jakarta: Salemba Medika.

RSUD P3 Gerung, (2018). Gerung: Data Rawat Inap Ruang Irna Anak.

Ramdaniati, (2011). Analisis Depertemen Kejadian Takut Pada Anak Pra Sekolah dan Sekolah yang Mengalami Hospitalisasi. Jakarta: Universitas Indonesia.

Setiadi, (2012). Konsep \& penulisan dokumentasi asuhan keperawatan. Yogyakarta: Graha Ilmu.

Soetjiningsih, (1998). Tumbuh Kembang Anak. Jakarta: EGC.

Stuart, Gail W. (2006). Buku Saku Keperawatan Jiwa. Edisi 5. Penerbit Buku Kedokteran : EGC.

Sugiyono, (2009). Metode Penelitian Bisnis (Pendekatan Kuantitatif, Kualitatif, dan R\&D). Bandung: Alfabeta.

Suherman, (2000). Buku Saku Perkembangan Anak. Jakarta: EGC.

Suliswati, S. Kp, M. Kes Dkk. (2005). Konsep Dasar Keperawatan Kesehatan Jiwa Jakarta : Penerbit Buku Kedokteran : ECG

Supartini, Yupi, (2004). Buku Ajar Konsep Dasar Keperawatan Anak. Jakarta: EGC.

Wong, (2004). Pedoman Perawatan Psikiatrik. Jakarta: EGC. 